\title{
Photoelectric Characterization of Dye Sensitized Solar Cells Using Natural Dye from Pawpaw Leaf and Flame Tree Flower as Sensitizers
}

\author{
Mohammed Isah Kimpa ${ }^{1^{*}}$, Musa Momoh ${ }^{2}$, Kasim Uthman Isah ${ }^{1}$, Hassan Nawawi Yahya ${ }^{3}$, \\ Muhammed Muhammed Ndamitso ${ }^{4}$ \\ ${ }^{1}$ Department of Physics, Federal University of Technology, Minna, Nigeria; ${ }^{2}$ Department of Physics, Usmanu Danfodiyo University, \\ Sokoto, Nigeria; ${ }^{3}$ Energy Research Centre, Usmanu Danfodiyo University, Sokoto, Nigeria; ${ }^{4}$ Department of Chemistry, Federal \\ University of Technology, Minna, Nigeria. \\ Email: *kimpabala2@yahoo.com
}

Received February $20^{\text {th }}, 2012$; revised March $27^{\text {th }}, 2012$; accepted April $28^{\text {th }}, 2012$

\begin{abstract}
Natural dyes from flame tree flower, Pawpaw leaf and their mixtures were used as sensitizers to fabricate dye-sensitized solar cells (DSSC). The photoelectrochemical performance of the Flame tree flower dye extract showed an open-circuit voltage $\left(\mathrm{V}_{\mathrm{OC}}\right)$ of $0.50 \mathrm{~V}$, short-circuit current density $\left(\mathrm{J}_{\mathrm{SC}}\right)$ of $0.668 \mathrm{~mA} / \mathrm{cm}^{2}$, a fill factor $(\mathrm{FF})$ of 0.588 and a conversion efficiency of $0.20 \%$. The conversion efficiency of the DSSCs prepared by pawpaw leaf extract was $0.20 \%$, with $\mathrm{V}_{\mathrm{OC}}$ of $0.50 \mathrm{~V}$; short-circuit current density, $\mathrm{J}_{\mathrm{SC}}$ of $0.649 \mathrm{~mA} / \mathrm{cm}^{2}$ and $\mathrm{FF}$ of 0.605 . The conversion efficiency for the flame tree flower and pawpaw leaf dye mixture was $0.27 \%$, with $\mathrm{V}_{\mathrm{OC}}$ of $0.518 \mathrm{~V}$, $\mathrm{J}_{\mathrm{SC}}$ of $0.744 \mathrm{~mA} / \mathrm{cm}^{2}$ and $\mathrm{FF}$ of 0.69 . Although the conversion efficiencies, Jsc and the Voc of the prepared dye cells were lower than the respective 1.185\%, 7.49 $\mathrm{mA} / \mathrm{cm}^{2}$ and $0.64 \mathrm{~V}$ reported for ruthenium, their fill factors (FF) were higher than that of ruthenium (0.497). It was also observed that both the short-circuit current density and the fill factors of the cells were enhanced using mixed dye.
\end{abstract}

Keywords: Dye-Sensitized Solar Cells; Flame Tree Flower; Pawpaw Leaf; Dye Cocktails; Natural Dyes

\section{Introduction}

Ddye-sensitized solar cells (DSSCs) are third generation solar cells developed by O'Regan and Gratzell in 1991 [1]. It converts inexpensive photon from solar energy to electrical energy based on sensitization of wide band gap semiconductor dyes and electrolytes [2]. In this process, several subsystems which work in tandem are interlaced with the adsorbed dye on a semiconductor surface that absorbs the visible and near-IR photons and pumps electrons into the conduction band of the semiconductor which is the electron-mediator for "hole" conduction and the counter electrode catalytic material [3]. The performance of the DSSC is highly dependent on the sensitizer dye and wide band gap material such as $\mathrm{TiO}_{2}, \mathrm{SnO}_{2}$, $\mathrm{ZnO}$ and $\mathrm{Nb}_{2} \mathrm{O}_{5}$ [4]. $\mathrm{TiO}_{2}$ is highly preferable due to its ability to resist the continuous transfer of electron under illumination (in the ultraviolet range). Several studies have addressed the use of $\mathrm{SnO}_{2}$ and $\mathrm{ZnO}[5,6]$. In general, the performance of dye absorption on the surface of $\mathrm{TiO}_{2}$ molecule determines the efficiency of the solar cell [2] and DSSCs efficiencies of up to $10.4 \%$ have been

${ }^{*}$ Corresponding author. reported for devices employing nanocrystalline $\mathrm{TiO}_{2}$ films [7]. One of the most efficient sensitizers is produced from the heavy transition metal coordination compound, ruthenium polypyridyl complex which is used widely due to its intense charge-transfer (CT) absorption in the visible light spectrum; good absorption, long excited lifetime and highly efficient metal-to-ligand charge transfer (MLCT) [8]. Ruthenium based complexes are however very expensive and hard to prepare, which restricts their large-scale applications in solar cells, stimulating the search for alternatives such as organic dyes [9]. Organic dyes with similar characteristics and even higher absorption coefficients used for DSSCs with efficiencies of up to $9 \%$ have been reported [10-12]. Organic dyes with higher absorption coefficients could translate into thinner nanostructured metal oxide films. This is advantageous for charge transport both in the metal oxide and in the permeating phase, allowing for the use of higher viscosity materials such as ionic liquids, solid electrolytes or hole conductors [13]. Organic dyes used in the DSSC do resemble dyes found in plants, fruits and other natural products and several of these have been used in the production of dye-sensitized solar cells [13-15]. Among 
the advantages of natural dyes is their easy availability, environmentally friendly, ease of fabrication, low process temperature and low cost of sensitization material production.

Naturally most fruits, flowers and leaves show various colours and contain several pigments which are easily extracted and then employed in DSSCs [16]. The leaves of most green plants are rich in chlorophyll and its application as natural dye has been investigated in many related studies $[4,17,18]$. Anthocyanins are natural compounds that give colour to fruits and plants and are also largely responsible for the purple-red color of autumn leaves and the red colour of flower buds [19]. In this paper, anthocyanin extracts of flame tree flower, chlorophyll extract from pawpaw leaf and their mixture were the natural dyes used as dye-sensitizers for the preparation of DSSCs.

The flame tree (Delonix regia), also known as royal Poinciana or flamboyant, is a member of the bean family (Leguminosae) widely regarded as one of the most beautiful tropical trees in the world [20]. The anthocyanins from the flame tree are composed of cyanidin 3-O-glucoside (Figure 1(a)) and cyanidin 3-O-rutinoside (Figure 1(b)) [21].

Pawpaw (Carica papaya Linnaeus), belongs to the family of Caricaceae. It is not a tree but an herbaceous succulent plants that posses self supporting stems of spongy and soft wood [22] Pawpaw is a large perennial herb with a rapid growth rate and thrives in tropical climate that is dry when cold and wet when warm [20] The leaves emerge directly from the upper part of the stem in a spiral on nearly horizontal petioles $30-105 \mathrm{~cm}$ long, hollow, succulent, green or more or less dark purple [23]

\section{Experimental Details}

\subsection{Extraction of the Natural Dyes}

Fresh flame tree flower and pawpaw leaves each of $10 \mathrm{~g}$ were separately weighed on an electronic weighing balance and crushed with a porcelain mortar and pestle, each crushed sample was then mixed with $50 \mathrm{~cm}^{3}$ of ethanol $(99 \%$ absolute) at room temperature in a dark room. Solid dregs in the solution were filtered by filter paper to acquire a pure and natural dye solution. Then, flame tree flower and pawpaw leaf extracts were blended at volume ratio of 1:1 to serve as a natural dye mixture.

\subsection{Preparation of DSSC}

The $\mathrm{TiO}_{2}$ film was prepared by blending $0.2 \mathrm{~g}$ of commercial $\mathrm{TiO}_{2}$ powder (Degussa, $\mathrm{P} 25$ ), $0.4 \mathrm{~cm}^{3}$ of nitric acid $(0.1 \mathrm{M}), 0.08 \mathrm{~g}$ of polyethylene glygol (MW 10,000) and one drop of a Triton x-100 (a nonionic surfactant). The mixture was well mixed using an ultrasonic bath for

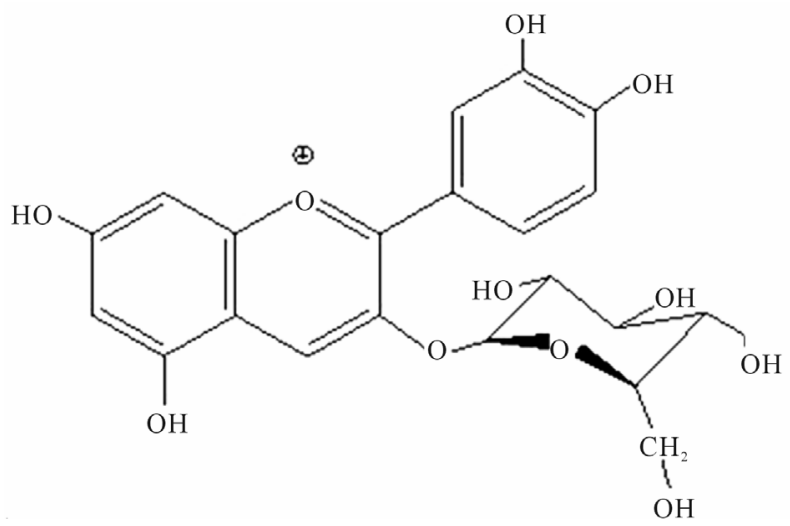

(a)

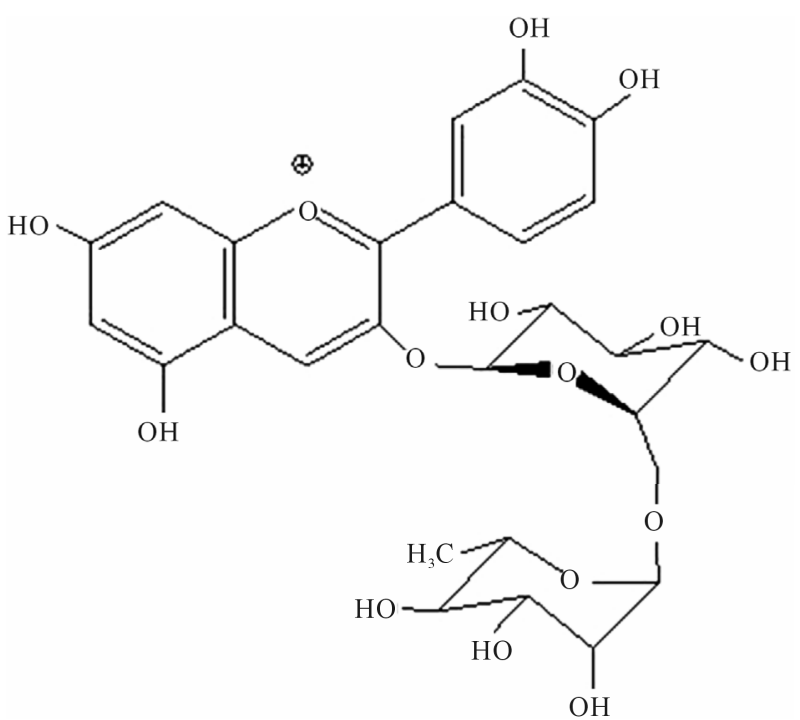

(b)

Figure 1. Chemical structure of (a) cyanidin 3-O-rutinoside and (b) Cyanidin 3-O-glucoside, main components of Flame tree flower anthocyanin.

$1 \mathrm{~h}$ and the resulting paste was spread over an FTO conductive glass plate (SOLARONIX) having $15 \Omega / \mathrm{cm}^{2}$. The $\mathrm{TiO}_{2}$ nano-particles thus produced had a mean particle size of $20 \mathrm{~nm}$. $\mathrm{TiO}_{2}$ pastes were deposited on the FTO conductive glass by rigid squeegee and screen printing procedure (polyester mesh of 90) in order to obtain a $\mathrm{TiO}_{2}$ film with a thickness of $18 \mu \mathrm{m}$. The active area of DSSC was $0.54 \mathrm{~cm}^{2}(1.4 \mathrm{~cm} \times 0.39 \mathrm{~cm})$. The $\mathrm{TiO}_{2}$ thin film was sintered at $450^{\circ} \mathrm{C}$ for $1 \mathrm{~h}$ to increase compactness of the thin film. The $\mathrm{TiO}_{2}$ film was consolidated through heat treatment, increasing the internal voids of film organization and thus enhancing its absorption performance. Then the sintered $\mathrm{TiO}_{2}$ thin film was immersed for $24 \mathrm{~h}$ in natural dyes prepared, allowing the natural dye molecules to be adsorbed on the surface of $\mathrm{TiO}_{2}$ nanoparticles. Anhydrous alcohol was used to remove any natural dye that had not been adsorbed on the 
surface of $\mathrm{TiO}_{2}$ nanoparticles. Finally, after cleaning, the DSSCs photoelectrode was complete and ready for testing.

Glass insulation spacers in long strips were used in assembling and these were stuck on the four edges of the base plate of conductive glass at the bottom. These formed a space between photoelectrode and counter electrode enabling the injection of electrolyte.

\subsection{Current Voltage Characterization}

In the performance test of the prepared DSSC, xenon (Xe) light of $150 \mathrm{~W}$ was selected to simulate sunlight (AM 1.5 ), and an I-V curve analyzer (Model 4200 SC) was employed to measure the photoelectric conversion efficiency of the prepared DSSC. The measured results were plotted in an I-V curve, from which the data of opencircuit voltage $\mathrm{V}_{\mathrm{oc}}(\mathrm{V})$, short-circuit current density $\mathrm{J}_{\mathrm{sc}}$ $\left(\mathrm{mA} / \mathrm{cm}^{2}\right)$, fill factor $(\mathrm{FF})$ and conversion efficiency $\eta \%$ were further acquired.

\section{Results and Discussion}

Figure 2 shows the SEM image of $\mathrm{TiO}_{2}$ nanoparticles fabricated using screen printing procedure. The $\mathrm{TiO}_{2}$ nanoparticles had a mean particle size of $20 \mathrm{~nm}\left(\mathrm{TiO}_{2}\right.$ nanoparticle that is well sintered enhanced the adsorptivity of natural dye molecules).

Absorption spectra provide necessary information on the absorption transition between the dye ground state and excited states and the solar energy range absorbed by the dye. Figures $\mathbf{3}$ and $\mathbf{4}$ show the absorption spectra of Flame tree flower and Pawpaw leaf dye extracts respectively as against N719 dye. The absorption range of N719 dye was from $400-600 \mathrm{~nm}$ with an absorption peak at $475 \mathrm{~nm}$. The flame tree flower dye extract had an absorption in the frequency range $350-500 \mathrm{~nm}$ with an absorption peak at $415 \mathrm{~nm}$. The chlorophyll dye extract from the pawpaw leaf had an absorption peak at $430 \mathrm{~nm}$ characteristic of chlorophyll pigment and an absorption range from $350-550 \mathrm{~nm}$. Chlorophyll absorbs most strongly in the blue and red regions of the absorption spectra.

Figure 5 shows the absorption spectrum of the mixed dyes from the flame tree flower and pawpaw leaves with the absorbability range of $350-500 \mathrm{~nm}$ while the absorption peak was at $430 \mathrm{~nm}$. This indicated that the absorption peaks of the mixed dye and that of pawpaw leaves dye were the same which could be as a result of them having the same colour or composition as different dyes show different absorption wavelengths due to differences in their compositions [24,25]. The weak absorption of the natural dye pigments in the red is a disadvantage, which affects the efficiency of the DSSC. The op-

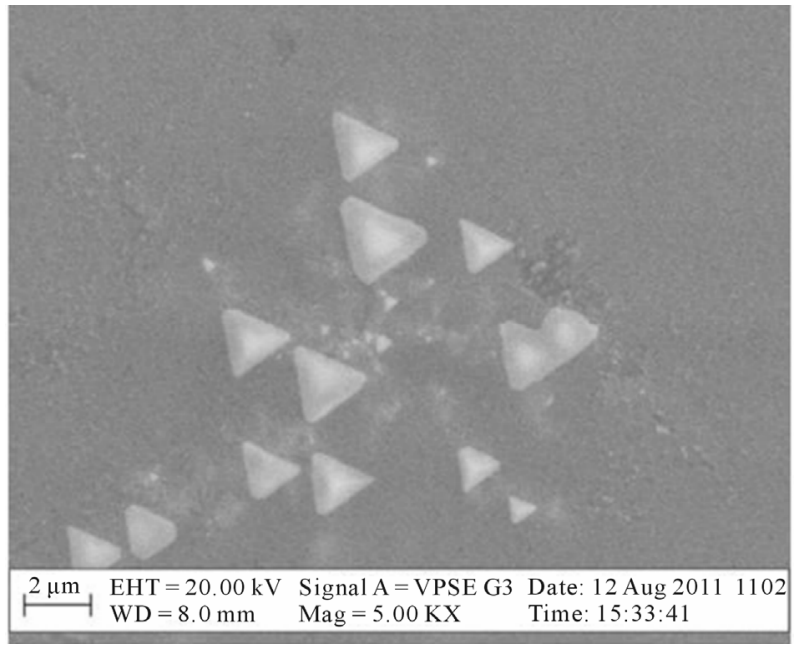

Figure 2. SEM image of fabricated $\mathrm{TiO}_{2}$.

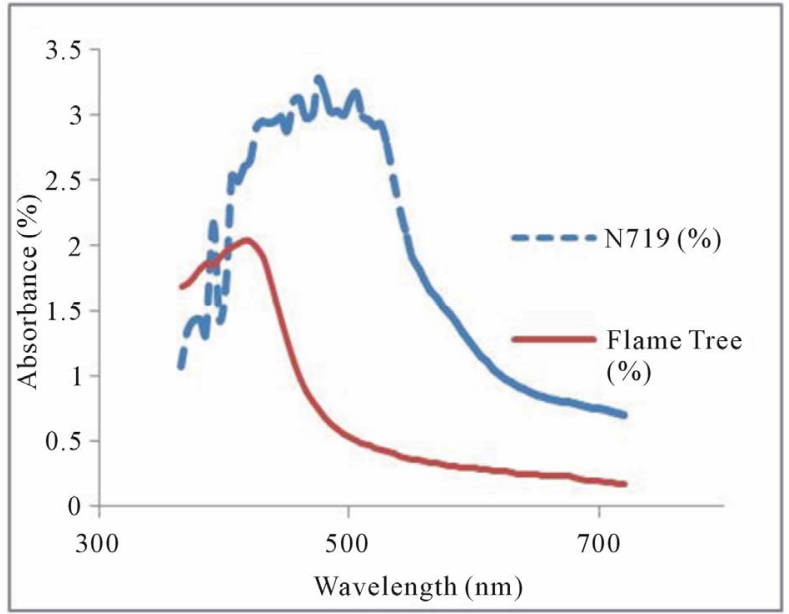

Figure 3. Absorption spectra of N719 dye and flame tree flower.

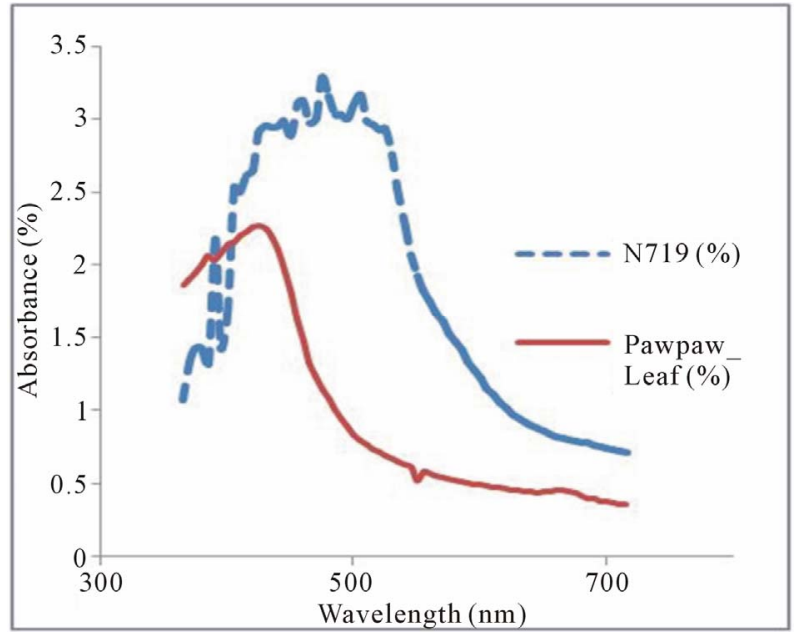

Figure 4. Absorption spectra of N719 dye and Pawpaw leave. 


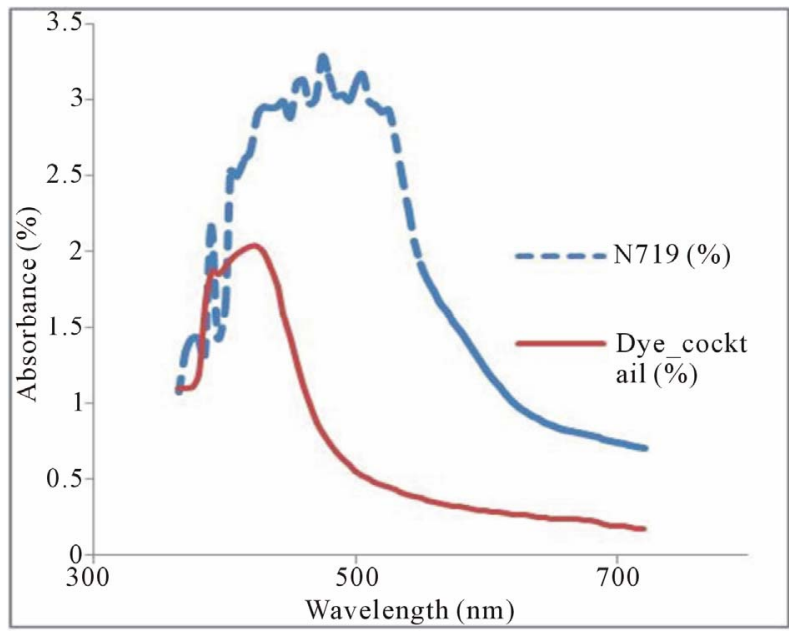

Figure 5. Absorption spectra of N719 dye and cocktail dye.

timization of the sensitizing dye, electrolyte solution and metal oxide surface chemistry will improve the solar cell performance.

Current-Voltage ( J-V) curves of solar cell gives important information on the operational parameters such as the short circuit current $I_{s c}$, open circuit voltage $V_{o c}$, the current $I_{m p}$ and voltage $V_{m p}$ at the maximum power point of a solar cell. Figure 6 shows the J-V characteristics of the prepared DSSC taking flame tree flower extract, pawpaw leaf extract and cocktail as the natural dye while ruthenium (N719) was characterized as a standard. Table 1 shows the data acquired from measuring the photoelectric conversion efficiency of the DSSCs.

The conversion efficiency of the DSSCs prepared from the dye extracted from flame tree flower is $0.20 \%$, with open-circuit voltage $\left(\mathrm{V}_{\mathrm{oc}}\right)$ of $0.503934 \mathrm{~V}$, short-circuit current density $\left(\mathrm{J}_{\mathrm{sc}}\right)$ of $0.668 \mathrm{~mA} / \mathrm{cm}^{2}$ and fill factor $(\mathrm{FF})$ of 0.588 . The conversion efficiency of the DSSCs prepared from dye extracted from pawpaw leaf was $0.20 \%$, with $\mathrm{V}_{\mathrm{oc}}$ of $0.503938 \mathrm{~V}$ and $\mathrm{J}_{\mathrm{sc}}$ of $0.649 \mathrm{~mA} / \mathrm{cm}^{2}$ and $\mathrm{FF}$ of 0.60526 . The conversion efficiency of $0.27 \%$ was recorded for the dye cocktails with $\mathrm{V}_{\mathrm{oc}}$ of $0.517958 \mathrm{~V}$ and $\mathrm{J}_{\mathrm{sc}}$ of $0.74418 \mathrm{~mA} / \mathrm{cm}^{2}$ and $\mathrm{FF}$ of 0.69 . The power conversion efficiency $(\eta)$ of the solar cells was calculated from the following equation:

$$
\eta=\frac{\mathrm{FF} \times \mathrm{J}_{\mathrm{sc}} \times \mathrm{V}_{\mathrm{oc}}}{\mathrm{P}_{\mathrm{in}}} \times 100 \%
$$

$P_{i n}$ is the power density of incident light [26].

From the result in Table 1, the DSSC of the combined dye mixture had improved photoelectric conversion efficiency. This is attributed to a synergistic sensitization by the dye mixture leading to higher efficiency [17]. The $\mathrm{V}_{\mathrm{oc}}$ of natural dye was lower than that of ruthenium dye which could have been because of molecular structure of

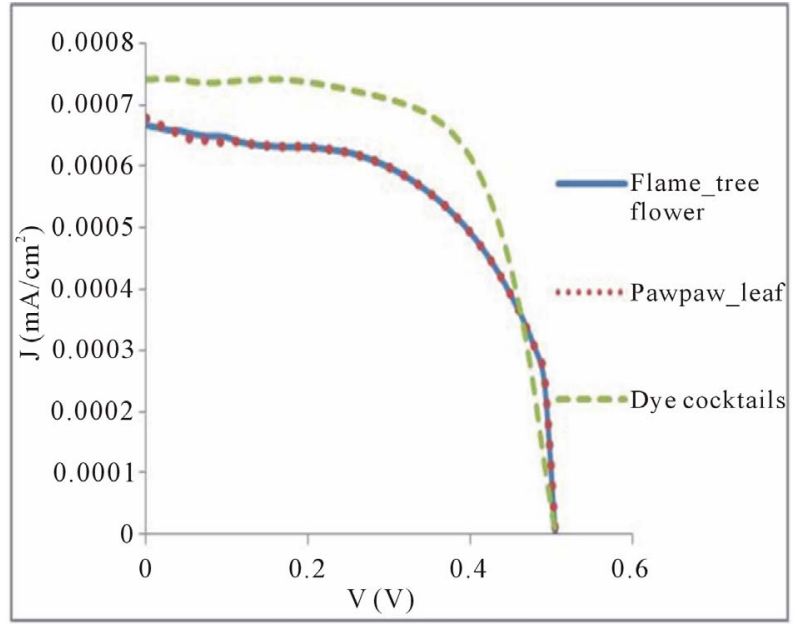

Figure 6. J-V characteristics of DSSCs with flame tree flower, pawpaw leaf and combination extracts dye.

Table 1. Characteristics of dye-sensitized solar cells.

\begin{tabular}{ccccc}
\hline Dye & $\mathrm{I}_{\mathrm{SC}}\left(\mathrm{mAcm}^{-2}\right)$ & $\mathrm{V}_{\mathrm{OC}}(\mathrm{mV})$ & $\mathrm{FF}$ & $\eta \%$ \\
\hline Ruthenium & 7.4920 & 0.639993 & 0.4972 & 1.185 \\
Flame tree flower & 0.6680 & 0.503934 & 0.5880 & 0.200 \\
Dye cocktail & 0.74418 & 0.517958 & 0.6900 & 0.270 \\
Pawpaw leaf & 0.6490 & 0.503938 & 0.6053 & 0.200 \\
\hline
\end{tabular}

natural dye which mostly has $\mathrm{OH}$ and $\mathrm{O}$ ligands that lack - $\mathrm{COOH}$ ligands possessed by ruthenium dye which combine with the hydroxyl of the $\mathrm{TiO}_{2}$ particles producing ester that boost coupling effect of electrons on $\mathrm{TiO}_{2}$ conduction band leading to a rapid electron-transport rate [27] These values were, however, comparable with those obtained for the DSSCs of frozen blackberries by Zhu et al. (2008) where $0.33 \mathrm{~V}$ was obtained as the open-circuit voltage while $0.59 \mathrm{~V}$ and $0.4 \mathrm{~V}$ were reported as the respective open circuit voltages for the DSSCs of dye extracts of blueberries and Jaboticaba's skin [28].

\section{Conclusion}

Dye sensitized solar cells were prepared from anthocyanin extracts of flame tree flower, chlorophyll extracts of pawpaw leaves, and a mixture of the two extracts. The photoelectric conversion efficiency with flame tree flower extract and pawpaw leaf extract as the natural dye both reach $0.20 \%$, while the conversion efficiency of dyesensitized solar cell from the mixed could reach as high as $0.27 \%$. The mixed dye has higher conversion efficiency than dyes prepared by either flame tree flower or pawpaw leaf extracts. Therefore, the mixed dye in this study provides a more efficient incident photon-to-electron conversion. The effect of mixed ratio of the dyes on 
the efficiency is being investigated further.

\section{Acknowledgements}

The authors are grateful to the Physics Advanced Laboratory, Sheda Science and Technology Complex (SHESTCO), Abuja, Nigeria for the use of their research facilities.

\section{REFERENCES}

[1] B. O'Regan and M. Gratzel, "A Low-Cost, High Efficiency Solar Cell Based on Dye-Sensitized Colloidal $\mathrm{TiO}_{2}$ Film," Nature, Vol. 353, No. 6346, 1991, pp. 737-740. doi: $10.1038 / 353737 \mathrm{a} 0$

[2] J. Bisquert, J. García-Cañadas, I. Mora-Seró and E. Palomares, "Comparative Analysis of Photovoltaic Principles Governing Dye-Sensitized Solar Cells and p-n Junctions," Proceedings of the SPIE, San Diego, 07 August 2003, pp. 49-59. doi:10.1117/12.506907

[3] S. Caramori, V. Cristino, R. Boaretto, R. Argazzi, C. A. Bignozzi and A. D. Carlo, "New Components for DyeSensitized Solar Cells," International Journal of Photoenergy, Vol. 2010, 2010, Article ID: 458614. doi: $10.1155 / 2010 / 458614$

[4] M. Gratzel, "Dye-Sensitized Solar Cell," Journal of Photochemistry \& Photobiology C: Photochemistry Reviews, Vol. 4, No. 2, 2003, pp. 145-153. doi:10.1016/S1389-5567(03)00026-1

[5] C. Bauer, G. Boschloo, E. Mukhtar and A. Hagfeldt, "Electron Injection and Recombination in $\mathrm{Ru}(\mathrm{dcbpy})_{2}(\mathrm{NCS})_{2}$ Sensitized Nanostructured ZnO," Journal of Phyical Chemistry B, Vol. 105, No. 24, 2001, pp. 5585-5588. dx.doi:10.1021/jp004121x

[6] M. Quintana, T. Edvinsson, A. Hagfeldt and G. J. Boschloo, "Comparison of Dye-Sensitized $\mathrm{ZnO}$ and $\mathrm{TiO}_{2}$ Solar Cells: Studies of Charge Transport and Carrier Lifetime," Journal of Physical Chemistry C, Vol. 111, No. 2, 2007, pp. 1035-1041. $\underline{\mathrm{dx} . d o i: 10.1021 / \mathrm{jp} 065948 \mathrm{f}}$

[7] M. K. Nazeeruddin, P. Pechy, T. Renouard, S. M. Zakeeruddin, R. Humphry-Baker, P. Comte, P. Liska, L. Cevey, E. Costa, V. Shklover, L. Spiccia, G. B. Deacon, C. A. Bignozzi and M. Gratzel, "Engineering of Efficient Panchromatic Sensitizers for Nanocrystalline $\mathrm{TiO}_{2}$-Based Solar Cells," Journal of the American Chemical Society, Vol. 123, No. 8, 2001, pp. 1613-1624. doi:10.1021/ja003299u

[8] S. Hao, J. Wu, Y. Huang and J. Lin, "Natural Dyes as Photosensitizers for Dye-Sensitized Solar Cell," Solar Energy, Vol. 80, No. 2, 2006, pp. 209-214. doi:10.1016/j.solener.2005.05.009

[9] H. Zhu, H. Zeng, V. Subramanian, C. Masarapu, K. H. Hung and B. Wei, "Anthocyanin-Sensitized Solar Cells Using Carbon Nanotube Films as Counter Electrodes," Nanotechnology, Vol. 19, No. 46, 2008, Article ID: 465204. doi:10.1088/0957-4484/19/46/465204

[10] K. Hara, Y. Dan-Oh, C. Kasada and H. Arakawa, "Effects of Additives on the Photovoltaic Performance of Cou-
marin-Dye-Sensitized Nanocrystalline TiO Solar Cells," Langmuir, Vol. 20, No. 10, 2004, pp. 4205-4210. doi:10.1021/la0357615

[11] S. Ito, S. M. Zakeeruddin, R. Humphry-Baker, P. Liska, R. Charvet, P. Comte, Md. K. Nazeeruddin, P. Pechy, M. Takata, H. Miura, S. Uchida and M. Gratzel, "High Efficiency Organic-Dye-Sensitized Solar Cells Controlled by Nanocrystalline TiO2 Electrode Thickness," Advanced Matererials, Vol. 18, No. 9, 2006, pp. 1202-1205. doi:10.1002/adma.200502540

[12] S. Kim, J.K. Lee, S. O. Kang, J. J. Ko, J. H. Yum, S. Fantacci, F. De Angelis, D. Di Censo, M. K. Nazeeruddin and M. Gratzel, "Molecular Engineering of Organic Sensitizers for Solar Cell Applications," Journal of American Chemical Society, Vol. 128, No. 51, 2006, pp. 1670116707. doi:10.1021/ja066376f

[13] K. Wongcharee, V. Meeyoo and S. Chavadej, "Dye-Sensitized Solar Cell Using Natural Dyes Extracted from Rosella and Blue Pea Flowers," Solar Energy Material Solar Cells, Vol. 91, No. 7, 2007, pp. 566-571. doi:10.1016/j.solmat.2006.11.005

[14] E. Yamazaki, M. Murayama, N. Nishikawa, N. Hashimoto, M. Shoyama and O. Kurita, "Utilization of Natural Carotenoids as Photosensitizers for Dye Sensitized Solar Cells," Solar Energy, Vol. 81, No. 4, 2007, pp. 512-516. doi:10.1016/j.solener.2006.08.003

[15] M. S. Roy, P. Balraju, M. Kumar and G. D. Sharma, "Dye-Sensitized Solar Cell Based on Rose Bengal Dye and Nanocrystalline TiO," Solar Energy Material Solar Cells, Vol. 92, No. 8, 2008, pp. 909-913. doi:10.1016/j.solmat.2008.02.022

[16] G. Calogero and G. D. Marco, "Red Sicilian Orange and Purple Eggplant Fruits as Natural Sensitizers for DyeSensitized Solar Cells," Solar Energy Material Solar Cell, Vol. 92, No. 11, 2008, pp. 1341-1346. doi:10.1016/j.solmat.2008.05.007

[17] K. Tennakone, G. R. R. A. Kumara, A. R. Kumarasinghe, P. M. Sirimanne and K. G. U. Wijayantha, "Efficient Photosensitization of Nanocrystalline $\mathrm{TiO}_{2}$ Films by Tannins and Related Phenolic Substances," Journal of Photochemistry \& Photobiology A: Chemistry, Vol. 94, No. 2-3, 1996, pp. 217-220. doi:10.1016/1010-6030(95)04222-9

[18] D. Zhang, S. M. Lanier, J. A. Downing, J. L. Avent, J. Lumc and J. L. McHale, "Betalain Pigments for DyeSensitized Solar Cells," Journal of Photochemistry Photobiology A: Chemistry, Vol. 195, No. 1, 2008, pp. 72-80. doi:10.1016/i.jphotochem.2007.07.038

[19] M. Rossetto, P. Vanzani, F. Mattivi, M. Lunelli, M. Scarpa and A. Rigo, "Synergistic Antioxidant Effect of Catechin and Malvidin 3-Glucoside on Free Radical-Initiated Peroxidation of Linoleic Acid in Micelles," Archives of Biochemistry and Biophysics, Vol. 408, No. 2, pp. 239-245. doi:10.1016/S0003-9861(02)00561-1

[20] IPIF, "Institute of Pacific Islands Forestry: Pacific Island Ecosystems at Risk," 2004. http://www.hear.org/pier/species

[21] A. Felix, F. L. Yves, M. Emmanuelle, L. Paul, A. Augustin, A. N. Georges and M. G. Emile, "Anthocyanin 
Characterization of Pilot Plant Water Extracts of Delonix regia Flowers," Molecules, Vol. 13, No. 6, 2008, pp. 12381245. doi:10.3390/molecules 13061238

[22] D. Gross, "Papaya: A Tantalising Taste of the Tropics. Maricopa County Master Gardener Volunteer information, University of Arizona Cooperative Extension," 2003. www.papayamaricopa-hort@ag.arizo.edu

[23] J. F. Morton, "Papaya Fruits of Warm Climates (Miami)," 1987.

www.hort.purdue.edu/newcrop/morton/papaya_ars.html

[24] A. S. Polo and N. Y. M. Iha, "Blue Sensitizers for Solar Cells: Natural Dyes from Calafate and Jaboticaba," Solar Energy Material Solar Cell, Vol. 90, No. 13, 2006, pp. 1936-1944. doi:10.1016/j.solmat.2006.02.006

[25] K. Hara, T. Horiguchi, T. Kinoshita, K. Sayama, H. Sugihara and H. Arakawa, "Highly Efficient Photon-to-Electron Conversion with Mercurochrome-Sensitized Nanoporous Oxide Semiconductor Solar Cells," Solar Energy
Material and Solar Cells, Vol. 64, No. 2, 2000, pp. 115134. doi:10.1016/S0927-0248(00)00065-9

[26] B. Pradhan, S. K. Batabyal and A. J. Pal, "Vertically Aligned $\mathrm{ZnO}$ Nanowire Arrays in Rose Bengal-Based Dye-Sensitized Solar Cells," Solar Energy Materials and Solar Cells, Vol. 91, No. 9, 2007, pp. 769-773. doi:10.1016/i.solmat.2007.01.006

[27] H. Chang and Y. Lo, "Pomegranate Leaves and Mulberry Fruit as Natural Sensitizers for Dye-Sensitized Solar Cells," Solar Energy, Vol. 84, No. 10, 2010, pp. 18331837. doi:10.1016/j.solener.2010.07.009

[28] A. O. T. Patrocinio, S. K. Mizoguchi, L. G. Paterno, C. G. Garcia and N. Y. M. Iha, "Efficient and Low Cost Devices for Solar Energy Conversion: Efficiency and Stability of Some Natural-Dye-Sensitized Solar Cells," Synthetic Metals. Vol. 159, No. 21-22, 2009, pp. 2342-2344. doi:10.1016/j.synthmet.2009.08.027 